\title{
STARtups of David
}

\section{WHY HAS ISRAEL BECOME A KEY MARKET FOR EARLY-STAGE INNOVATION?}

By Sherree DeCovny

Israel has produced so many successful technology startups that Tel Aviv is now considered the Silicon Valley of the Middle East. Venture capital funds from around the world are flocking to the country in search of the next big innovation. Several companies have been bought out by global giants, and scores of Israeli companies are listed on major foreign exchanges. So what is Israel's secret?

Israel is a small country with hostile neighbors and Israel attracts more ventures per capita than any other country, and $85 \%$ of the funding for Israeli high tech comes from abroad.

Cultural characteristics (such as high tolerance for failure) and national circumstances (such as mandatory military service) help give Israeli entrepreneurs an edge.

Although a "cultural transplant" is virtually impossible, other countries can learn from key aspects of Israel's example, such as the way Israel's government promotes and supports innovation and risk taking. limited natural resources, so Israelis are creative at finding workarounds and ways to scale globally. Out-of-thebox thinking is so ingrained in the culture that Israelis have an almost manic need to innovate. They are constantly looking to break molds and stretch boundaries.

"People in Israel don't stand in line," Gadi Toren, an investment partner at Robert Bosch Venture Capital (RBVC) in Tel Aviv, says halfjokingly. "It's the same cultural characteristic that also cient ways of doing things and challenge conventions. Even if people tell you it's impossimakes people find more effible, you still want to check it."

Importantly, Israelis have

a high tolerance for failure, and new startups are often born out of collapses. Modu, a telecommunications company, is a case in point. The company's founder, Dov Moran, invented the USB flash drive and sold his company, M-Systems, to SanDisk for $\$ 1.6$ billion in one of Israel's largest transactions. He then started Modu in 2007 and developed a very small and light modular smartphone. Moran recruited an excellent management team and board, raising $\$ 120$ million from investors, but three years later the company shut down because its smartphone could not compete with Apple's iPhone, which was much larger and consolidated apps onto one device. Modu's IP portfolio was sold to Google, and it formed the basis for the Google modular phone. Additionally, many former Modu employees have started their own companies.

\section{A MILITARY SECRET}

All able-bodied Israelis must serve in the Israel Defense
Forces (IDF), which happens to be a surprising advantage for some entrepreneurs. The military is the great leveler: No one cares about your socioeconomic background, and everyone has an opportunity to build a network of talented friends and acquaintances. The IDF is also a technologyintensive organization, providing a pathway for Israelis to develop skills in such key areas as cybersecurity.

A case in point is serial entrepreneur Ariel Maislos. Following a 10-year stint in the IDF, Maislos began developing technology for Israel's equivalent of the US National Security Agency. In 2001, he founded Passave, which offered fiber-to-the-home broadband communication technology. Passave was sold to PMC-Sierra in 2006, which was then acquired by Microsemi in 2016.

Next, Maislos founded Anobit, a flash storage company. After Anobit was acquired by Apple in 2012, he established and ran Apple's engineering center in Israel. At the time, this was one of Apple's largest acquisitions, as well as its first engineering center outside the United States.

"In both cases, we ended up with very successful financial outcomes for the founding team, employees, and investors," says Maislos. "The acquired companies were successful in leveraging the technology and the team for ongoing innovation. Anobit had about 200 employees in Israel when Apple acquired it, and the staff was expanded to 800."

In 2013, he founded Stratoscale, which is now developing tools to enable companies to leverage cloud technology. The undertaking is not only broad in scope but also requires innovation in many fields. Maislos attracted top investors to back the idea. He got Stratoscale off the ground by teaming up with Battery Ventures, which was also the seed investor in Anobit. Then he attracted other investors, including Bessemer Venture Partners, Intel Capital, Cisco Systems, SanDisk (recently acquired by Western Digital), and Leslie Ventures. Maislos hopes to start marketing the technology later in 2016.

\section{MULTINATIONAL VENTURE CAPITAL}

Multinational firms' investment arms in Israel serve as a window to the global markets. Venture capital firms have offices there so they can be close to early-stage innovation and provide mentorship and funding. Successful Israeli entrepreneurs are also investing back into the ecosystem.

"About $85 \%$ of the funding in Israeli high tech originates from abroad," says Inbal Arieli, vice president of strategic partnerships at Start-Up Nation Central in Tel Aviv. "That figure has been stable for many years now, which speaks for the talent that exists here."

MS Ventures, the corporate venture arm of Merck in Germany, has committed to invest up to about $€ 10$ million 
in early-stage opportunities through its Israel Bioincubator Fund. It has invested in Metabomed, a company focusing on the discovery and development of potential smallmolecule drugs directed against novel targets in the field of cancer metabolism. Based on its proprietary interdisciplinary target identification platform, Metabomed's unique approach to discovery allows it to potentially identify new targets that form a synthetic lethal gene pair with metabolic genes inactivated in cancer cells. By inhibiting these targets, Metabomed intends to develop more-selective anti-cancer drugs that could be highly targeted, sparing normal cells.

Metabomed recently completed an extension of its Series A round from current and new investors, bringing the total to $\$ 18$ million. Other investors include Boehringer Ingelheim Venture Fund, Pontifax Venture Capital, the Technion Research \& Development Foundation, Pfizer, and Arkin Holdings. Metabomed will continue gathering data and experimenting to prove its hypothesis. If the work is successful, either a partner will provide additional funding or the company will be acquired.

Merck plans to build on its presence in Israel to create companies from scratch, as it did with Metabomed. Moreover, its commitment has formed a bridge for other investors from the pharmaceutical industry. Novartis has invested in an incubator company called BioLineRx, which it plans to use as a scouting branch to look for other early-stage investments in Israel. Furthermore, Johnson \& Johnson joined forces with Takeda Pharmaceutical Company's venture group, the Office of the Chief Scientist in Israel, and OrbiMed Israel Partners in an incubator called FutuRx.

"You now have a paradigm for large pharma to optimize the way they're going to access Israeli technology," says Simone Botti, former head of MS Ventures Israel Bioincubator Fund and now CEO of Metabomed. "You have different models. Each one is finding the best formula for accessing innovation."

Founded in 2008, RBVC is the corporate venture company of the Bosch Group, a global supplier of mobility solutions, industrial technology, consumer goods, and energy and building technology. RBVC opened its Israel office in 2009 , and its structure is similar to private venture partnerships. There is an operational wall between RBVC and Bosch's other business units. The organization reports to the CEO of Bosch, but it does not require the parent company's approval to make an investment. It can even invest in competitors, although it does so infrequently.

Facebook acquired one of RBVC's investments, Pebbles Interfaces, a developer of motion sensors for 3D gesture interaction, for $\$ 60$ million in July 2015 . Another portfolio company, Cheetah Medical, offers decision support systems in the management of cardiac output.

"We need to be convinced that a company is of strategic importance and relevance to Bosch, as well as an interesting investment opportunity," says Toren. "It's not enough for it to be just one of the two."

Being an active investor is important. RBVC almost always has some form of board representation, and it supports startups by helping to devise strategies that will make money and result in a successful exit. It also facilitates relations with Bosch in various forms, including joint development, managing the customer-supplier relationship, and distribution, all the way up to the point of acquisition.

The startup is not obliged to do anything with Bosch, however, and Bosch is not obliged to do anything with the startup. RBVC takes a large minority position, normally between $10 \%$ and $25 \%$. It's flexible in terms of its position in the investment rounds and willing to syndicate and invest alongside other investors.

\section{REPLICATING SUCCESS}

Israel attracts more venture capital per capita than any other country. It has the highest density of startups in the world, and it ranks third in the world in innovation according to the World Economic Forum's Global Competitiveness Report 2015-2016. Generally, investors perceive it as being an island of stability in the region. According to Deloitte's "2015 Global Venture Capital Confidence Survey," for the last five years global investor confidence in Israel has been second only to that in the United States.

According to Arieli, valuations of Israeli companies are slightly lower on average than those of Silicon Valley companies, but they are higher than those in Europe. However, competition has increased over the past decade as more countries recognize that innovation, technology, and entrepreneurship are sources of economic strength.

"All those numbers are great, but there's potential for so much more," she says. "We need to increase the pool of talent that's involved in high tech and involve larger portions of the workforce in this sector, which is a growth engine of the economy."

The Israeli government has been proactive in policymaking and risk taking to support innovation. Israel's Office of the Chief Scientist, which is being renamed the Israel Innovation Authority, has contributed significant funding for loans that startup companies must repay only if they are successful. Applicants must submit an R\&D plan and budget, and they need to report to the Innovation Authority and be examined to ensure they meet certain quality standards.

Other countries could replicate this model to encourage innovation and invest in their future, but a complete cultural transplant would be almost impossible.

"In most cases, it's very difficult to take the essence out of something and transfer it to another place where the geographical, political, and social parameters are really different," Botti notes. "What you can try to do is to understand the components that go into a suc-
KEEP GOING

"Emerging Markets: How to Better Understand and Mitigate Risk Going Forward," CFA Institute Take 15 Series (May 2016) [www.cfainstitute.org]

"Geopolitical Risk: Emerging Trends and Hot Spots," 2016 Middle East Investment Conference video webcast (April 2016) [www.cfainstitute.org] cessful model and see how to best implement the ones that have the highest chance of success given your environment."

Sherree DeCovny is a freelance journalist specializing in finance and technology. 